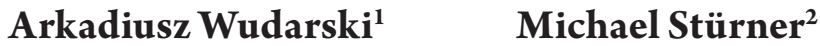

\section{Glosa do wyroku Trybunału Konstytucyjnego z dnia 16 listopada 2011 r., SK 45/09, Dz.U. 2011, Nr 254, poz. $1530^{3}$}

\section{Glówne tezy}

1. Stanowisko Trybunału Konstytucyjnego pokrywa się co do zasadniczych kwestii z orzecznictwem niemieckiego Federalnego Sądu Konstytucyjnego. Mimo to problem kolizji krajowego i europejskiego porządku prawnego nadal pozostaje nierozwiązany.

2. Należy dążyć do równowagi pomiędzy istotnym dla rynku wewnętrznego postulatem swobody przepływu orzeczeń, a prawami procesowymi dłużnika, w szczególności zasadą rzetelnego procesu oraz wywodzonym z niej prawem do sądu. Dopuszczając ograniczenia dostępu do sądów krajowych w miejscu wykonania orzeczenia, kluczowe znaczenie ma gwarancja przestrzegania wymienionych zasad procesowych w państwie członkowskim, w którym wydano orzeczenia.

3. Orzeczenie Trybunału Konstytucyjnego daje impuls do zbadania, czy kontrola innych norm europejskiego prawa procesowego, w sto-

1 Autor jest profesorem oraz kierownikiem Katedry Polskiego i Europejskiego Prawa Prywatnego oraz Komparatystyki Prawa na Europejskim Uniwersytecie Viadrina we Frankfurcie nad Odrą oraz kierownikiem Zespołu Badawczego Europejskiego Prawa Prywatnego i Porównawczego w Akademii im. Jana Długosza w Częstochowie.

2 Autor jest profesorem oraz kierownikiem Katedry Prawa Cywilnego, Międzynarodowego Prawa Prywatnego oraz Komparatystyki Prawa na Uniwersytecie w Konstancji oraz sędzią w Sądzie Okręgowym w Karlsruhe.

Artykuł powstał z wersji niemieckojęzycznej publikowanej w czasopiśmie „Praxis für Internationales Privat- und Verfahrensrecht (IPRax)”, Gieseking Verlag. Autorzy składają podziękowania za pomoc w przekładzie pani mgr Karolinie Wróblewskiej. 
sunku do których Trybunał zastrzega sobie taką kompetencję, mogłoby doprowadzić do kolizji regulacji.

4. Przyjęta przez Trybunał Konstytucyjny proeuropejska wykładnia polskiej Konstytucji pozwala mieć nadzieję, że również w przyszłości podobne konflikty będą rozstrzygane na korzyść rynku wewnętrznego.

\section{Stan faktyczny i przedmiot skargi konstytucyjnej}

Trybunał Konstytucyjny musiał po raz pierwszy rozstrzygnąć w sprawie dopuszczalności kontroli zgodności norm prawa pochodnego Unii Europejskiej z Konstytucją ${ }^{4}$. Orzeczenie Trybunału było konsekwencją wniesienia skargi konstytucyjnej, w której zakwestionowano zgodność z Konstytucją postępowania uregulowanego w rozporządzeniu w sprawie jurysdykcji i uznawania orzeczeń sądowych oraz ich wykonywania w sprawach cywilnych i handlowych (Bruksela I) ${ }^{5}$. Na tym tle Trybunał musiał wypowiedzieć się w kwestiach zasadniczych, tj. określić wzajemny stosunek norm prawa unijnego do prawa konstytucyjnego państw członkowskich oraz rozgraniczyć kompetencje Europejskiego Trybunału Sprawiedliwości (ETS) i krajowych trybunałów konstytucyjnych ${ }^{6}$.

Orzeczenie Trybunału Konstytucyjnego zostało wydane na podstawie następującego stanu faktycznego: skarżąca została zobowiązana prawomoc-

4 Dotychczasowe orzecznictwo Trybunału odnosiło się już wprawdzie do stosunku prawa polskiego do pierwotnego i pochodnego prawa unijnego, ale nie dotykało wprost istoty problemu; zob. TK z dnia 11 maja 2005 r., K 18/04, OTK-A 2005 nr 5, poz. 49; TK z dnia 24 listopada 2010 r., K 32/09, OTK-A 2010 nr 9, poz. 108; TK z dnia 17 grudnia 2009 r., U 6/08, OTK-A 2009 nr 11, poz. 178; TK z dnia 19 grudnia 2006 r., P 37/05, OTK-A 2006 nr 11, poz. 177.

5 Rozporządzenie Rady (WE) nr 44/2001 z dnia 22 grudnia 2000 r. (Dz.Urz. UE L 12 z dnia 16 stycznia 2001 r.), s. 1 .

6 Omówienie wyroku w polskim piśmiennictwie zob. M. Jackowski, Przegląd Orzecznictwa Trybunału Konstytucyjnego, „Palestra” 2012, nr 5-6, s. 211 i n.; T. Jaroszyński, Glosa do wyroku z 16 XI 2011, SK 45/09, „Państwo i Prawo” 2012, z. 9, s. 130 i n.; P. Bogdanowicz, P. Marcisz, Szukając granic kontroli - glosa do wyroku TK z 16.11.2011 r. (SK 45/09), „Europejski Przegląd Sądowy” 2012, nr 9, s. 47 i n.; A. Chmielarz, Kontrola konstytucyjności prawa pochodnego Unii Europejskiej, „Przegląd Sejmowy” 2012, nr 4, s. 9 i n. 
nym orzeczeniem Sądu Apelacyjnego w Brukseli do zapłaty 12.500 EUR? Kwotę zasądzono tytułem odszkodowania za szkody materialne i niematerialne, które powód poniósł wskutek popełnienia przez skarżącą przestępstwa przeciwko jego życiu i zdrowiu. Dnia 11 maja 2006 r. powód złożył wniosek o stwierdzenie wykonalności na terenie Rzeczpospolitej Polskiej postanowienia sądu belgijskiego. Właściwy w sprawie Sąd Okręgowy Warszawa-Praga ustalił bez udziału skarżącej, że przewidziane w rozporządzeniu Bruksela I przesłanki zostały spełnione i stwierdził wykonalność orzeczenia Sądu Apelacyjnego w Brukseli. Wniesiony przez skarżącą środek odwoławczy nie został uwzględniony ${ }^{9}$. Dnia 9 lipca 2007 r. skarżąca wniosła skargę konstytucyjną, w której zakwestionowała między innymi zgodność art. 41 zd. 2 rozporządzenia Bruksela I z Konstytucją Rzeczpospolitej Polskiej, przytaczając następujące uzasadnienie:

1. Art. 41 zd. 2 rozporządzenia Bruksela I nie daje dłużnikowi, przeciwko któremu zapadło orzeczenie sądu zagranicznego, prawa do złożenia jakichkolwiek wyjaśnień w pierwszej instancji postępowania o stwierdzenie wykonalności orzeczenia sądu zagranicznego. Wykluczenie uczestnika $\mathrm{z}$ udziału w postępowaniu sądowym w pierwszej instancji narusza jego prawo do sądu oraz sprawiedliwego postępowania, a tym samym art. 45 ust. 1 Konstytucji.

2. Art. $41 \mathrm{zd} .2$ rozporządzenia Bruksela I narusza jednocześnie sformułowaną w art. 32 Konstytucji zasadę równości, która nakazuje między innymi równe traktowanie wszystkich przez władze publiczne. Odnosi się to w szczególności do postępowań sądowych, w których każda strona powinna mieć równe prawo przedstawienia swojego stanowiska. W ramach sądowego stwierdzenia wykonalności orzeczenia sądu zagranicznego prawo do wysłuchania w pierwszej instancji zostało tymczasem przyznane wyłącznie wnioskodawcy (wierzycielowi).

3. Postępowanie sądowe o stwierdzenie wykonalności orzeczenia sądu zagranicznego, co do którego zastosowanie znajduje kwestionowana

7 Postanowienie z dnia 23 grudnia 2004 r., nr 1289/2004.

8 Postanowienie z dnia 24 sierpnia 2006 r., III Co 33/06.

9 Postanowienie Sądu Apelacyjnego w Warszawie z dnia 9 marca 2007 r., VI ACz $1877 / 06$. 
norma rozporządzenia Bruksela I, jest sprzeczne $\mathrm{z}$ art. $78 \mathrm{i}$ art. 176 ust. 1 Konstytucji, które konstytuują zasadę dwuinstancyjności postępowania sądowego. Samo prawo do zaskarżenia postanowienia o wykonalności orzeczenia sądu zagranicznego nie czyni zadość powyższej zasadzie, która obejmuje również prawo do aktywnego udziału stron w postępowaniu w każdej instancji. Ponadto w pierwszej instancji sprawa nie była rozpatrywana merytorycznie, a tym samym nie można mówić o jej ponownym rozpoznaniu w postępowaniu apelacyjnym, gdyż dopiero na tym etapie uczestnicy mogli przedstawić swoje dowody i argumenty.

4. Dopuszczalność kontroli konstytucyjności prawa pochodnego Unii Europejskiej przez Trybunał jest uzasadnione prymatem konstytucji w systemie źródeł prawa. Konstytucja jest najwyższym prawem Rzeczpospolitej Polski, a jej przepisy stosuje się bezpośrednio (art. 8 Konstytucji). Jeżeli unijne rozporządzenie ogranicza określone w Konstytucji prawa i wolności, nie ma obowiązku jego przestrzegania. Art. 91 ust. 3 Konstytucji dotyczy tylko pierwszeństwa prawa unijnego w przypadku kolizji z ustawą. Nie odnosi się to jednakże do norm konstytucyjnych.

\section{Orzeczenie Trybunału Konstytucyjnego}

Trybunał Konstytucyjny nie uwzględnił wniesionej skargi konstytucyjnej, stwierdzając tym samym zgodność art. $41 \mathrm{zd} .2$ rozporządzenia Bruksela I z art. 45 ust. 1 oraz art. 32 ust. 1 w związku z art. 45 ust. 1 Konstytucji. W uzasadnieniu Trybunał podniósł między innymi następujące argumenty:

1. Akt normatywny w rozumieniu art. 79 ust. 1 Konstytucji, podlegający konstytucyjnej kontroli, może zostać wydany nie tylko przez polskie organy prawodawcze, ale również - po spełnieniu dodatkowych warunków - przez organy międzynarodowych organizacji, których Polska jest członkiem. Odnosi się to przede wszystkim do rozporządzeń Unii Europejskiej (por. nr III. 1.3-5, 2.2 wyroku).

2. Przy badaniu zgodności z Konstytucją aktów pochodnego prawa unijnego zaleca się zachowanie szczególnej ostrożności i powścią- 
gliwości oraz poszanowanie zasady lojalnej współpracy (art. 4 ust. 3 TUE) (por. nr III. 2.5. wyroku).

3. Pozbawienie dłużnika w art. $41 \mathrm{zd} .2$ rozporządzenia Bruksela I możliwości złożenia oświadczeń w pierwszym etapie procedury realizuje istotne cele postępowania o stwierdzenie wykonalności orzeczenia sądu zagranicznego (swobodny przepływ i skuteczność wykonywania orzeczeń na terenie Unii Europejskiej, budowanie wzajemnego zaufania do wymiaru sprawiedliwości) i nie narusza prawa do sądu (por. nr III. 6.7 wyroku).

4. Szczególny charakter postępowania o stwierdzenie wykonalności orzeczenia sądu zagranicznego pozwala na zróżnicowanie praw procesowych stron w pierwszej instancji. $Z$ art. $41 \mathrm{zd} .2$ rozporządzenia Bruksela I nie wynika nadmierne i nieuzasadnione uprzywilejowanie wierzyciela wobec dłużnika (por. nr III. 7 wyroku).

5. Sporna norma rozporządzenia Bruksela I nie narusza prawa do zaskarżenia orzeczenia przed sądem wyższej instancji. Nawet gdyby procedura sądowa w pierwszej instancji nie była należycie ukształtowania, nie uzasadnia to naruszenia prawa do zaskarżenia orzeczenia pierwszej instancji oraz zasady dwuinstancyjności postępowania (por. nr III. 5.5 wyroku).

\section{Komentarz}

I.

Pierwsza zasadnicza konkluzja zawarta w wyroku odnosi się do zagadnień stricte konstytucyjnych. Trybunał wskazuje na wyższą rangę Konstytucji w stosunku do prawa pochodnego Unii Europejskiej, co w konsekwencji pozwala na kontrolę konstytucyjności europejskich rozporządzeń i dyrektyw $^{10}$. Ten punkt widzenia, zresztą dość sporny w polskim piśmiennictwie ${ }^{11}$,

10 Krytycznie: P. Bogdanowicz, P. Marcisz, Szukając granic kontroli-glosa..., s. 47, 50.

11 Stanowiska w polskim piśmiennictwie są zróżnicowane: T. Jaroszyński, Rozporzadzenie wspólnotowe jako przedmiot skargi konstytucyjnej, „Europejski Przegląd Sądowy” 2007, nr 4, s. 26, 28 i n.; A. Chmielarz, Kontrola konstytucyjności prawa..., s. 9, 11 i n. z podaną tam literaturą. 
odbiega od wykładni przyjętej na gruncie prawa unijnego, zgodnie z którą prawo unijne ma pierwszeństwo przed prawem krajowym, w tym również prawem konstytucyjnym państw członkowskich ${ }^{12}$. Tymczasem prawo pochodne Unii Europejskiej stanowi w ocenie Trybunału „akt normatywny" w rozumieniu art. 79 ust. 1 Konstytucji ${ }^{13}$ i tym samym może być przedmiotem skargi konstytucyjnej ${ }^{14}$. Choć przyjęte przez Trybunał stanowisko zostało oparte na argumentach formalnych, to nie jest ono pozbawione racji. Rozporządzenia mają bowiem - zgodnie z art. 288 ust. 2 TFUE - zasięg ogólny oraz wiążą w całości i obowiązują bezpośrednio we wszystkich krajach członkowskich. Z punktu widzenia obywateli jest więc bez znaczenia, czy ich konstytucyjne prawa zostaną ograniczone przez polski czy europejski akt władzy publicznej. W konsekwencji należy przyjąć, iż dopuszczalność konstytucyjnej kontroli prawa pochodnego Unii Europejskiej nie ogranicza się wyłącznie do wniesienia skargi konstytucyjnej, lecz obejmuje także pytania prawne o zgodność z konstytucją aktu normatywnego, które każdy sąd może - zgodnie z art. 193 Konstytucji - przedstawić Trybunałowi w ramach kontroli konstytucyjności „konkretnej” normy ${ }^{15}$.

Z drugiej jednak strony wiele przemawia też za tym, żeby tylko polskie akty normatywne uznać za przedmiot skargi konstytucyjnej. W państwowym systemie trójpodziału władzy prawo pochodne Unii Europejskiej stanowi element obcy, ponieważ nie zostało wydane zgodnie z polską procedurą ustawodawczą i pozostaje w związku z tym poza zasięgiem polskiej konstytucji. Bez wątpienia natomiast przedmiotem kontroli konstytucyjnej byłaby ustawa implementująca prawo pochodne Unii Europejskiej.

12 TSUE, wyrok z dnia 15 lipca 1964 r., w sprawie 6/64 - Costa / ENEL, Zb.Orz. 1964, 1251, 1269; por. też TSUE, wyrok z dnia 22 października 1987, w sprawie 314/85 Foto Frost / Hauptzollamt Lübeck-Ost, Zb.Orz. 1987, I-4199.

13 Aprobująco: W. Czapliński, Integrationsverantwortung aus polnischer Sicht, [w:] Integrationsverantwortung, red. M. Pechstein, Baden-Baden 2012, s. 112; P. Bogdanowicz, P. Marcisz, Szukając granic kontroli - glosa..., s. 47, 48; tak również przed wydaniem decyzji T. Jaroszyński, Rozporządzenie wspólnotowe jako przedmiot skargi..., s. 26, 37.

14 Odnośnie przedmiotu skargi konstytucyjnej por. M. Jackowski, Przegląd Orzecznictwa Trybunatu, s. 211, 213 i n.; T. Jaroszyński, Rozporządzenie wspólnotowe jako przedmiot skargi..., s. 26, 27 i n.

15 Szerzej A. Chmielarz, Kontrola konstytucyjności prawa..., s. 9, 23 i n. 
Również niemiecki Federalny Sąd Konstytucyjny (Bundesverfassungsgericht) zastrzega sobie prawo do kontroli zgodności aktów prawnych Unii Europejskiej z Ustawą Zasadniczą (Grundgesetz $\left.{ }^{16}\right)^{17}$. Niemniej jednak niemieckie prawo konstytucyjne reguluje w art. 23 Ustawy Zasadniczej ${ }^{18}$ europejską klauzulę integracyjną, z której wynika „pierwszeństwo z mocy konstytucyjnego umocowania"19. Tym samym uprawnienia kontrolne ograniczają się do oceny, czy zakreślone tam granice nie zostały przekroczone. Jednakże każde stwierdzenie nieważności przepisów prawa Unii Europejskiej przez krajowy sąd konstytucyjny musi zostać poprzedzone postępowaniem prejudycjalnym zgodnie $\mathrm{z}$ art. $267 \mathrm{TFUE}^{20}$. W sprawie kontroli zgodności prawa pochodnego Unii Europejskiej z prawami podstawowymi niemiecki Federalny Sąd Konstytucyjny od czasu orzeczenia „Solange II” stoi na stanowisku, że jego władza sądownicza tak długo nie będzie wykonywana, dopóki w Unii Europejskiej gwarantowana jest ochrona praw podstawowych na poziomie porównywalnym z niemiecką Ustawą Zasadniczą ${ }^{21}$.

Pod tym względem polski Trybunał Konstytucyjny zdaje się w punkcie wyjścia iść o krok dalej niż sąd niemiecki, nawet jeśli w swojej argumentacji odwołuje się bezpośrednio do orzecznictwa Solange II $^{22}$. Różnica ta nie może

16 Ustawa z dnia 23 maja 1949 r., ostatnio zmieniona przez art. 1 ustawy z dnia 11 lipca 2012 r. (BGBl. I S. 1478).

17 BVerfGE 89, 155, 175 (Maastricht); BverfGE 123, 267, 353 i n., nb. 240, 241 (Lissabon); BVerfG 126, 286, 302 nb. 54 i n. (Honeywell).

18 Art. 23 ust. 1 UZ brzmi: „W celu urzeczywistnienia zjednoczonej Europy Republika Federalna Niemiec współuczestniczy w rozwoju Unii Europejskiej, zobowiązanej do przestrzegania zasad demokracji, praworządności, polityki socjalnej i federalizmu i zasady subsydiarności oraz zapewniającej ochronę praw podstawowych porównywalną w swej istocie z niniejszą Ustawą Zasadniczą. Władze federalne mogą w związku z tym poprzez ustawę wymagającą zgody Bundesratu przekazać pewne prawa suwerenne. W odniesieniu do uzasadnienia odwołanie się do Unii Europejskiej oraz do zmian jej zasad traktatowych i porównywalnych regulacji prawnych, w wyniku których treść niniejszej Ustawy Zasadniczej zostaje zmieniona lub uzupełniona lub tego rodzaju zmiany i uzupełnienia stają się możliwe, stosuje się przepis art. 79 ust. 2 i 3" - przekład www.warschau.diplo.de (5.01.2013).

19 BverfGE 123, 267, 397 nb. 332 (Lissabon).

20 Zob. A. Haratsch, Ch. Koenig, M. Pechstein, Europarecht, wyd. 7, 2011, nb. 147.

${ }^{21}$ BverfGE 73, 339, 378 i n., 387. Ten pogląd został skonkretyzowany i potwierdzony w orzeczeniu w sprawie „Bananenmarkt”.

22 Zob. nr III. 2.8, szerzej nr III. 8.2-8.4. 
jednakże wpływać na ostateczne rozstrzygnięcie. Jak podkreśla sam Trybunał Konstytucyjny, przy kontroli zgodności prawa unijnego z Konstytucją należy zachować szczególną powściągliwość, a przyznanie państwom członkowskim kompetencji do uchylania aktów prawa pochodnego ciężko pogodzić z zasadą lojalności sformułowaną w art. 4 ust. 3 TUE. Ta ostatnia uwaga przypomina postulat współpracy z Europejskim Trybunałem Sprawiedliwości wyrażony przez niemiecki Federalny Sąd Konstytucyjny w wyroku Maastricht ${ }^{23}$. Polski Trybunał Konstytucyjny powołuje się również wyraźnie na niemieckie orzeczenie w sprawie „Honeywell”, w którym akcentowana jest subsydiarna funkcja krajowego sądu konstytucyjnego w stosunku do prawa unijnego ${ }^{24}$. Słusznie i zarazem zgodnie z literaturą wskazuje, iż uchylenie kwestionowanej normy europejskiego prawa pochodnego pociągnęłoby za sobą postępowanie przeciwko Polsce w sprawie naruszenia prawa Unii Europejskiej (art. 258 i n. TFUE). Takie działanie możliwe byłoby jedynie jako ultima ratio i wymagałoby wcześniejszego rozważenia zmian w polskiej Konstytucji ${ }^{25}$. Taka zmiana miała już miejsce w 2008 r. w związku z wprowadzeniem europejskiego nakazu aresztowania ${ }^{26} \mathrm{i}$ ugruntowała wyraźnie prymat prawa unijnego, osłabiając znaczenie Konstytucji jako prawa najwyższego. Inne rozwiązania (zmiana kwestionowanej normy prawa unijnego lub wystąpienie z Unii Europejskiej) są wprawdzie teoretycznie możliwe, ale politycznie nie do przeforsowania ${ }^{27}$. Decydujące jest jednak, że prawa i wolności zagwarantowane w polskiej Konstytucji pokrywają się na ogół z tymi przyznanymi na płaszczyźnie europejskiej, a niektóre nawet wywodzą się z nich. Stąd też istnieje małe praw-

23 BverfGE 89, 155, 175.

24 Proeuropejskie wykonywanie kontroli ultra vires, BverfG 126, 286, 303 i n., nb. 58 i n. (Honeywell).

25 Godne uwagi jest, że Trybunał Konstytucyjny na poparcie swojego stanowisko uwzględnia badania prawnoporównawcze; wskazuje na to w szczególności powołanie się na: Relacje między prawem konstytucyjnym a prawem unijnym w orzecznictwie sądów konstytucyjnych państw Unii Europejskiej, red. K. Zaradkiewicz, Warszawa 2011, w którym badany jest stosunek pomiędzy prawem konstytucyjnym a prawem unijnym w orzecznictwie trybunałów konstytucyjnych państw członkowskich.

26 Por. zmiana art. 55 Konstytucji (dopuszczalność ekstradycji polskiego obywatela). Ustawa z dnia 8 września 2006 r. o zmianie Konstytucji Rzeczypospolitej Polskiej (Dz.U. Nr 200, poz. 1471).

27 Por. P. Bogdanowicz, P. Marcisz, Szukając granic kontroli-glosa, s. 47, 52. 
dopodobieństwo, iż zagwarantowany w prawie europejskim poziom ochrony praw i wolności jednostki w porównaniu ze standardem narzuconym przez polską Konstytucję pozwoli na stwierdzenie niezgodności norm prawa unijnego z Konstytucją ${ }^{28}$. Różnice w sformułowaniach, względnie zastosowaniu prawa powinny być usuwane w drodze wykładni przez Europejski Trybunał Sprawiedliwości. Również od skarżącego będzie się w przyszłości wymagać, aby uwiarygodnił, iż standard ochrony jego praw podstawowych w prawie pochodnym Unii Europejskiej znacznie odbiega od standardu konstytucyjnego. W tak bardzo wąskich ramach przyjętych przez Trybunał Konstytucyjny przyjęcie skargi, a także orzeczenie o niekonstytucyjności prawa pochodnego Unii Europejskiej jest wprawdzie formalnie dopuszczalne, aczkolwiek w praktyce prawie niemożliwe ${ }^{29}$. W rezultacie stanowisko Trybunału Konstytucyjnego pokrywa się co do zasadniczych kwestii z orzecznictwem niemieckiego Federalnego Sądu Konstytucyjnego. Orzeczenie polskiego Trybunału Konstytucyjnego pokazuje jednak wyraźne starania, aby przynajmniej w formalnym aspekcie pogodzić ze sobą pozycję Konstytucji jako prawa najwyższego oraz Trybunału Konstytucyjnego jako sądu „ostatniego słowa” z kompetencjami Europejskiego Trybunału Sprawiedliwości oraz pierwszeństwem zastosowania prawa unijnego. Mimo to problem kolizji krajowego i europejskiego porządku prawnego nadal pozostaje nierozwiązany ${ }^{30}$.

II.

Druga istotna kwestia dotyczy oceny konstytucyjności postępowania w sprawie stwierdzenia wykonalności orzeczenia sądu zagranicznego uregulowanego w rozporządzeniu Bruksela I. W tym zakresie skarżąca podniosła w istocie podwójny zarzut: postępowanie ex parte, prowadzone w celu stwierdzania wykonalności orzeczenia, narusza konstytucyjnie zagwarantowane prawo do sądu, a postępowanie odwoławcze nie czyni zadość zasadzie dwuinstancyjności, gdyż jedynie w instancji odwoławczej postępowanie ma charakter kontradyktoryjny. Od wydanego w tym postępowaniu orze-

\footnotetext{
28 Ibidem, s. 47, 50, 51, 52.

29 Por. W. Czapliński, op.cit., s. 113.

30 Por. A. Chmielarz, Kontrola konstytucyjności prawa..., s. 9, 31.
} 
czenia nie przysługuje jednak żaden środek odwoławczy. Jak słusznie stwierdził Trybunał Konstytucyjny, oba zarzuty nie zasługują na uwzględnienie.

System transgranicznego wykonywania orzeczeń w rozporządzeniu Bruksela I przewiduje, $w$ interesie przyspieszenia i swobody przepływu orzeczeń, szybkie i efektywne postępowanie. Samo przeprowadzenie postępowania o stwierdzenie wykonalności orzeczenia sądu zagranicznego, zgodnie $\mathrm{z}$ art. 38 ust. 1 rozporządzenia Bruksela I, jest wprawdzie konieczne, ale zakres kontroli sądu w państwie wykonania orzeczenia jest jednak bardzo ograniczony i obejmuje w zasadzie jedynie kwestie formalne, o których mowa $\mathrm{w}$ art. 53 i art. 54 rozporządzenia Bruksela I. W konsekwencji zarzuty dłużnika w tym stadium postępowania dopuszcza się tylko w ograniczonym zakresie. Dzięki temu można osiągnąć efekt zaskoczenia i zapobiec działaniom dłużnika utrudniającym zaspokojenie wierzyciela. $Z$ tych względów - zgodnie z art. 41 zd. 2 rozporządzenia Bruksela I - nie przewiduje się na tym etapie postępowania przesłuchania dłużnika. Dopiero postępowanie odwoławcze ma charakter kontradyktoryjny, na co wyraźnie wskazuje art. 43 ust. 3 rozporządzenia Bruksela I. Prawo do sądu może zatem zostać ograniczone albo nawet wyłączone w celu przyśpieszenia wykonania orzeczenia. Takie ograniczenie jest zgodne z zasadą proporcjonalności, ponieważ dłużnik może na wniosek wszcząć kontradyktoryjne postępowanie odwoławcze. Ponadto art. 47 ust. 3 rozporządzenia Bruksela I zapewnia, że egzekucja z majątku dłużnika do chwili rozpoznania środka zaskarżenia może obejmować jedynie środki zabezpieczające. Zagadnienie, czy tak ukształtowane postępowanie instancyjne odpowiada wymogom polskiej Konstytucji, nie może zostać zgłębione w ramach tego opracowania. Odpowiedź wydaje się być jednak twierdząca, jeżeli przyjmiemy, jak to czyni Trybunał Konstytucyjny, że art. 176 Konstytucji gwarantuje tylko możliwość odwołania się do sądu wyższej instancji, nie stawia natomiast szczególnych wymogów co do ukształtowania postępowania odwoławczego ${ }^{31}$. Na marginesie warto zwrócić uwagę, iż zgodnie z przeważającym poglądem w literaturze niemieckiej prawo do dwuinstancyjnego postępowania nie jest zagwarantowane w niemieckiej konstytucji ${ }^{32}$.

31 Zob. nr III. 5.

32 Zob. BverfGE 54, 277, 291; za konstytucyjnym prawem do dwuinstancyjnego postępowania: A. Voßkuhle, Rechtschutz gegen den Richter, 1993; M. Stürner, Die Anfechtung von 
Nawet jeśli skarga konstytucyjna okazała się w rezultacie niezasadna, to orzeczenie Trybunału Konstytucyjnego daje impuls do zbadania, czy kontrola innych norm europejskiego prawa procesowego, w stosunku do których Trybunał zastrzega sobie taką kompetencję, mogłoby doprowadzić do kolizji regulacji. Rozważania można rozpocząć od analizy tego samego stanu faktycznego w hipotetycznej sytuacji obowiązywania rozporządzenia Bruksela I w zmienionej formie. Obecne postępowanie o stwierdzenie wykonalności orzeczenia sądu zagranicznego ma być w wyniku planowanych zmian jeszcze bardziej korzystne dla wierzyciela. Jak wiadomo, Komisja zaproponowała bowiem całkowite zniesienie procedury exequatur i tym samym pełną swobodę przepływu orzeczeń sądowych w Unii Europejskiej ${ }^{33}$. W konsekwencji dłużnik miałby być pozbawiony możliwości podnoszenia jakichkolwiek zarzutów, w tym zarzutu naruszenia ordre public. Nawet jeśli Rada w swoim projekcie ${ }^{34}$ dyskutowanym na posiedzeniu w dniach 7-8 czerwca 2012 r. nie przyjęła tak daleko idącej zmiany ${ }^{35}$, to i tak dalej opowiada się za rezygnacją z procedury exequatur ${ }^{36}$. Również projekt Parlamentu z dnia 25 września 2012 r. $^{37}$ był z tym zbieżny ${ }^{38}$. W rezultacie ten kierunek zmian oddaje nowe brzmienie rozporządzenia Bruksela I (art. 39 lub 46 w zw. z art. 45), które zostało wydane 12 grudnia 2012 r. ${ }^{39} \mathrm{Na}$ tym tle pojawia się pytanie, czy zarzut naruszenia prawa do sądu w postępowaniu o stwierdzenie wykonalności wyroku sądu zagranicznego, który skarżąca bezskutecznie podnosiła w obowiązującej wersji rozporządzenia Bruksela I, zostałby uwzględniony po jego nowelizacji? Na takie pytanie należy udzielić odpowiedzi przeczącej, ponieważ punkt wyjścia w przedmiotowej sprawie

Zivilurteilen, 2002, 50 i n.; zob. też BVerfGE 107, 395; A. Voßkuhle, Bruch mit einem DogmaDie Verfassung garantiert Rechtsschutz gegen den Richter, NJW 2003, s. 2193.

$33 \operatorname{KOM}(2010)$ 748; zob. M. Weller, Der Kommissionsentwurf zur Reform der Brüssel I-VO, GPR 2012, s. 34-36.

34 Dokument Rady 10609/12 JUSTCIV 209 CODEC 1495 ADD 1 z 1.6.2012 r. Zob. M. Weller, Der Ratsentwurf und der Parlamentsentwurf zur Reform der Brüssel I-V0, GPR 2012, s. 328.

\footnotetext{
35 Zob. art. 48 ust. 1 projektu Rady.

36 Zob. art. 39-2 projektu Rady.

37 Dok.-Nr. PE496.504v01-00; referent: T. Zwiefka; dazu M. Weller, GPR 2012, s. 328.

38 Art. 39 b oraz art. 48 ust. 1 projektu Parlamentu.

39 Rozporządzenie nr 1215/2012 (Dz.Urz. UE L.2012.351.1).
} 
nie ulega zmianie. Jeśli bowiem postępowanie ex-parte, które było przyczyną wniesienia skargi konstytucyjnej, zostanie zlikwidowane, to dalej pozostaje możliwość skorzystania ze środka odwoławczego, co czyni zadość prawu do sądu.

Być może ocena byłaby jednak odmienna, gdyby wziąć pod uwagę takie rozporządzenia, które nie znają ani procedury exequatur, ani też jakichkolwiek innych sposobów zaskarżenia orzeczeń w państwie wykonania. Chodzi w szczególności o rozporządzenie w sprawie utworzenia Europejskiego Tytułu Egzekucyjnego dla roszczeń bezspornych ${ }^{40}$, rozporządzenie ustanawiające postępowanie w sprawie europejskiego nakazu zapłaty ${ }^{41}$ oraz rozporządzenie ustanawiające europejskie postępowanie w sprawie drobnych roszczeń $^{42}$. Sytuacja dłużnika jest tutaj szczególnie trudna, gdyż w państwie wykonania orzeczenia jest on całkowicie pozbawiony możliwości sądowego przedstawienia swojego stanowiska. Zgodnie z koncepcją przyjętą w tych rozporządzeniach zarzuty przeciwko wykonalności tytułu egzekucyjnego mogą być podnoszone jedynie w państwie jego wydania, a nie wykonania $^{43}$. Jednak nawet w takiej sytuacji nie można mówić o naruszeniu prawa do sądu, ponieważ w państwie wykonania nie toczy się żadne postępowanie, w ramach którego mogłoby ewentualnie dojść do naruszenia prawa. Tym niemniej przeciwko takiemu modelowi transgranicznej egzekucji podnieść można o wiele poważniejsze zarzuty. Dotyczą one jednak w większym stopniu samej istoty swobodnego przepływu orzeczeń niż określonego postępowania o stwierdzenie wykonalności orzeczenia sądu zagranicznego. Rozgraniczyć należy przy tym sytuacje, w których naruszenie prawa do sądu ma miejsce w postępowaniu wyjściowym (pierwotnym) oraz przypadki, w których dłużnik chciałby się bronić przed egzekucją w innym państwie członkowskim za pomocą dostępnych tam środków prawnych ${ }^{44}$.

\footnotetext{
40 Rozporządzenie nr 805/2004 z dnia 21 kwietnia 2004 r. (Dz.Urz. UE L.2004.143.15).

${ }^{41}$ Rozporządzenie nr 1896/2006 z dnia 12 grudnia 2006 r. (Dz.Urz. UE L.2006.399.1).

42 Rozporządzenie nr 861/2007 z dnia 11 lipca 2007 r. (Dz.Urz. UE L.2007.199.1).

43 Szerzej na przykładzie rozporządzenia nr 805/2004, M. Stürner, [w:] Hk-ZV, wyd. 2, 2012, Art. 1 EuVTVO nb. 1.

44 Szerzej M. Stürner, Rechtsschutz gegen fehlerhafte Europäische Vollstreckungstitel, GPR 2010, s. 43.
} 
W takiej sytuacji zawsze warto dążyć do osiągnięcia równowagi pomiędzy istotnym dla rynku wewnętrznego postulatem swobody przepływu orzeczeń, effet utile każdego rozporządzenia, a prawami procesowymi dłużnika, w szczególności zasadą rzetelnego procesu (art. 6 ust. 1 EKPC) oraz wywodzonym $\mathrm{z}$ niej prawem do sądu. W coraz silniej integrującej się Europie, w interesie wspólnego rynku wewnętrznego, trzeba zatem dopuścić ograniczenia dostępu do sądów krajowych. Zasadnicze znaczenie wydaje się mieć tutaj gwarancja przestrzegania wymienionych zasad procesowych także wówczas, gdy dostęp do sądu jest możliwy tylko w tym państwie członkowskim, w którym wydano orzeczenia. Przyjęta przez Trybunał Konstytucyjny proeuropejska wykładnia polskiej Konstytucji pozwala mieć nadzieję, że również w przyszłości podobne konflikty będą rozstrzygane na korzyść rynku wewnętrznego. 